DOI: https://doi.org/10.32839/2304-5809/2021-11-99-22

УДК 504(477.41-2)

Шевченко В.Г., Лагутенко О.Т., Настека Т.М. Національний педагогічний університет імені М.П. Драгоманова Шевченко В.Ю.

Київський національний торговельно-економічний університет

\title{
ЕКОЛОГО-БІОЛОГІЧНИЙ СТАН ТА ОСНОВНІ ЕКОЛОГІЧНІ ПРОБЛЕМИ СЕЛА РУСАНІВ БРОВАРСЬКОГО РАЙОНУ КИЇВСЬКОЇ ОБЛАСТІ
}

\begin{abstract}
Анотація. В залежності від конкретного природного середовища, розвитку інфраструктури, особливостей забудови, діючих виробництв, наявних рекреаційних зон, у різних населених пунктах складаеться певна еколого-біологічна ситуація. Визначено основні чинники негативного впливу на еколого-біологічний стан компонентів довкілля села Русанів Броварського району. Через Русанів протікае річка Трубіж, на акваторії якої спостерігається замулення, зниження водності. Через село проходить автомобільна дорога державного значення Н-07 Київ - Суми - Юнаківка, яка впливае на ряд показників якості повітря. Хвойні та листяні ліси навколо села відносяться до державного підприемства «Бориспільське лісове господарство», що здійснюе системи рубок головного користування та рубки для формування і оздоровлення лісів. На території села знаходиться об’ект екологічної мережі - заказник ботанічний «Оврамівсько-Івашківський». Тут виявлено місцезростання лілії лісової, занесеної до Червоної книги України. Сформульовано пропозиції щодо мінімізації антропогенно-техногенного впливу на природне середовище.
\end{abstract}

Ключові слова: довкілля, екологічний стан, екологічні проблеми, село Русанів, річка Трубіж.

Shevchenko Valentyna, Lagutenko Oksana, Nasteka Tatiana National Pedagogical Dragomanov University

Shevchenko Valeriia

Kyiv National University of Trade and Economics

\section{ECOLOGICAL AND BIOLOGICAL SITUATION AND THE MAIN ECOLOGICAL PROBLEMS OF RUSANIV VILLAGE, BROVARY DISTRICT, KYIV REGION}

Summary. Significant aggravation of environmental problems leads to a degradation in quality of life, as well as to the emergence of serious social problems, such as increased morbidity, mortality, reduce of working age and life expectancy. Depending on the specific natural environment, development of infrastructure, features of buildings, existing production facilities, as well as existing recreational areas, different populated areas have their own specific ecological and biological situation. Therefore, the main factors that negatively affect the ecological and biological state of the environment components of Rusaniv village, Brovary district, are identified. Trubizh river flows through Rusaniv village, on the waters of which siltation and lowering of the water level are observed. Also, the watersheds and areas along the river are being plowed. Various types of economic activity lead to the ingress of harmful chemicals into the water. For example, the norms of maximum permissible concentrations of ammonium nitrogen and nitrite nitrogen are exceeded in the surface waters of the Trubizh river. Besides, the principal road H-07 Kyiv-Sumy-Yunakivka passes through the village, which affects a number of air quality indicators. The air quality index calculated for the main air pollutant - fine dust, fraction PM2.5 - in most cases is average during the day and ranges from 66 to 100 units. Coniferous and deciduous forests around the village are at the disposal of the State Enterprise "Boryspil Forestry», which carries out deforestation for various purposes. Under the influence of anthropogenic factors, the quantitative and qualitative composition of flora and fauna undergoes certain changes. This is a consequence of the plowing of lands, agricultural works, reduction of forests, shrubs, as well as fires in large areas, especially during the burning of dead woods in spring and autumn. In addition, the emergence of spontaneous landfills on the territory and outside the Rusaniv village limits points to the lack of environmental awareness of its citizens. On the territory of Rusaniv village, there is an object of the ecological network - the Botanical Reserve "Ovramivsko-Ivashkivskyi». In the reserve, there are forests, where oaks predominate. Also, it is possible to find the forest lily, which is listed in the Red Book of Ukraine. Considering the above, the proposals for minimizing the anthropogenic and technological impact on the environment are formulated.

Keywords: environment, ecological state, environmental problems, Rusaniv village, Trubizh river.

$\Pi^{2}$ остановка проблеми. Негативні зміни в екологічному стані довкілля викликають занепокоєння. Питання стосовно екологічної ситуації в Україні хвилюе кожного четвертого громадянина $(25,6 \%)$ [1, с. 5]. Суттеве загострення екологічних проблем навколишнього середовища призводить до погіршення якості життя, а також до виникнення серйозних сощіальних проблем: зростання захворюваності, смертності, скорочення працездатного віку та тривалості життя [8; 16].

Аналіз останніх досліджень і публікацій. В регіональних доповідях про стан навколиш- нього природного середовища Київської області та в інших наукових виданнях в основному висвітлюються проблеми на районних рівнях та в межах міст $[6 ; 7 ; 14]$. Проте, на основі досліджень, які викладені в публікації групи авторів разом з Балюк С. занепокоєність екологічними проблемами власного населеного пункту кожного громадянина $є$ досить вагомою [1, с. 5]. Тому дослідження стану навколишнього середовища невеликих поселень є актуальним.

Виділення не вирішених раніше частин загальної проблеми. В залежності від кон- 
кретного природного середовища, розвитку інорраструктури, особливостей забудови, діючих виробництв, наявних рекреаційних зон, у різних населених пунктах складається певна екологічна ситуація. Аналіз стану навколишнього середовища здійснюеться головним чином у великих містах, а в невеликих населених пунктах ця робота проводиться на недостатньому рівні. Екологічні проблеми існують на територіях невеликих поселень і ці проблеми потребують окремого вивчення для розробки ефрективних механізмів та програм у вирішенні місцевих, регіональних і зальнодержавних екологічних питань.

Мета статті. Головною метою ціеї роботи $\epsilon$ виявлення основних еколого-біологічних особливостей села Русанів та аналіз сучасних екологічних проблем цієї місцевості.

Виклад основного матеріалу. Село Русанів розташоване на сході Броварського району Київської області, за 30 км від міста Бровари та 47 км від міста Киева і є адміністративно-територіальним центром Русанівської сільської ради [13]. В селі розвинена інженерно-транспортна інфраструктуpa, воно газифіковане, електрифріковане. Сучасний Русанів налічуе 1811 жителів, має 978 дворів, щільність населення 283,19 осіб/км² [9].

Село розташоване в межах Дніпровської терасової рівнини, яка являє собою акумулятивну низовину, складену товщею водно-льодовикових і алювіальних відкладів, тому рельеф місцевості рівнинний, абсолютна висота території складае від 106,0 м до 107,4 м. Поверхня 3 невеликими перепадами рельефу, відмітки висот якої коливаються в межах 1-2 м [3].

Клімат району дослідження - помірно-континентальний. Спостерігаеться помірна посушливість 3 теплим тривалим літом та помірно-холодна, часом нестійка зима, з невеликим сніговим покривом та частими тривалими відлигами [4, с. 5].

Ірунти - в основному чорноземні, родючі, з великим вмістом гумусу, в незначній кількості супіски, суглинки та солонці, які при необхідних агрономічних заходах дають великі урожаї. По долині річки Трубіж значні території займають борові хвилясті тераси, де розповсюджені дерново-середньопідзолисті грунти [5, с. 13]. Ерозійні процеси на території села майже не спостерігаються, оскільки рельеф має невеликі перепади.

Село розміщено на території з численними річковими долинами і за гідрологічними показниками - це місцевість 3 багатими підземними водами у водоносних горизонтах. Через Русанів протікає річка Трубіж (відноситься до середніх річок). Стан річки в районі дослідження незадовільний, оскільки спостерігається її замулення, зниження водності (рис. 1). Природно-кліматичні зміни, зниження середньорічних показників кількості опадів, антропогенний вплив призвів до деградації водної екосистеми і порушення їі природно-екологічної рівноваги. Знищення рослинності по берегах річки, розорювання водозборів і прилеглих до річки площ негативно впливає на їі стан. Так, у 2021 році були розорані вздовж p. Трубіж в районі с. Русанів великі території 3 природною лучною рослинністю і засаджені сільськогосподарськими культурами. В наслідок цього до водойми додатково будуть надходити забруднюючі речовини: мінеральні добрива, пес- тициди, гербіциди. У результаті спостережень за станом забруднення водних об'єктів Київської області у 2020 р. характерними забруднювачами річок були сполуки азоту, важких металів, френолу [11, с. 39]. Перевищення норм ГДК у поверхневих водах р. Трубіж було зафіксовано стосовно азоту амонійного та азоту нітритного.

На території села Русанів відсутні підприємства та виробництва, які б призводили до забруднення повітря. Але через село проходить автомобільна дорога державного значення Н-07 Київ - Суми - Юнаківка, яку з весни 2021 року активно ремонтують в рамках програми Президента України Володимира Зеленського «Велике будівництво». Рух автомобілів цією автотрасою досить активний і це сприяє погіршенню деяких показників якості повітря, зокрема індекс якості атмосферного повітря, розрахований за формулою NowCast (US EPA) для головного забрудника повітря - дрібнодисперсного пилу фрракції РМ2.5 в більшості є середнім протягом доби і становить від 66 до 100 одиниць. Проте ці показники можуть збільшуватись до шкідливого рівня для чутливих груп та шкідливого рівня в ранішні і вечірні години [12].

Збільшення індексу якості повітря означає, що в цей період чутливі групи, такі, як діти, люди похилого віку, у кого є респіраторні та захворювання серцево-судинної системи можуть відчувати погіршення самопочуття.

Досліджувана місцевість відноситися до зони лісостепу 3 широко розповсюдженим характерним типом рослинності. Доповнюе видовий склад інтрозональна рослинність водних долин, зокрема р. Трубіж.

Відповідно до геоботанічного районування територія належить до Лівобережнодніпровського округу липово-дубових, грабово-дубових, соснових (на терасах) лісів, луків, галофітної та болотної рослинності.

На лучних, водних і в лісових біотипах розповсюджена фрауна, представлена характерними видами.

Під дією антропогенних впливів у кількісному і якісному складі фрлори і фрауни відбуваються значні зміни. Це пов'язано з розорюванням природних угідь, проведенням сільськогосподарських робіт, зменшенням площі лісів, чагарників, виникненням пожеж на значних територіях, зокрема під час підпалювання сухостою у весняний та осінній періоди.

Село Русанів оточують хвойні, листяні та змішані ліси, які відносяться до державного підприемства «Бориспільське лісове господарство» Київського обласного управління лісового та мисливського господарств [5]. Ліси лісгоспу віднесено до рівнинних. Ростуть соснові, дубові насадження $з$ домішкою липи, граба, клена, берези, осики. ДП «Бориспільський лісгосп» під час своєї планової діяльності застосовує системи рубок головного користування та рубки для формування і оздоровлення лісів. Під час такої діяльності прогнозований обсяг порубкових решток складає від 10 до 18\%, залежно від ліквідної деревини, від категорії деревостанів та їх санітарної ліквідності. Лісгоспом також зазначено, що не менше 95\% порубкових решток підлягають утилізації. Найтовстіше гілля, яке за своєю структурою чи якісними показниками не підпадає ні під один із сортів потрібної деревини розрізуеться та вико- 


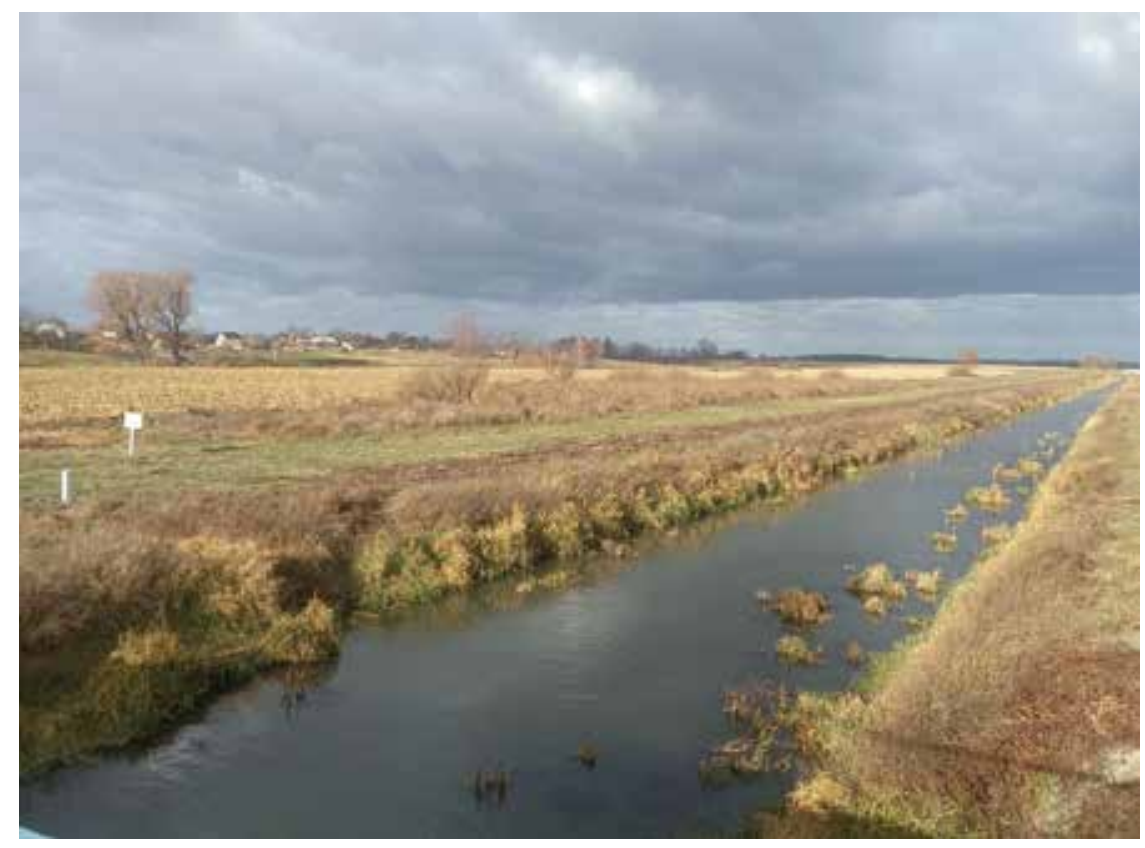

Рис. 1. Річка Трубіж в селі Русанів Київської області

ристовуеться для забезпечення потреб населення, а гілля меншого діаметру, а також залишки пнів та коріння сухостійних дерев - на деревну тріску - щепу, що використовуеться для виробництва франери, меблів, деревно-волокнистих плит, а також на виготовлення паливних брикетів, пелетів тощо. Залишковим хмизом устеляються трелювальні дороги. Частина хмизу складуеться у купи для природнього перегнивання, що сприяє розвитку природнього біоценозу на лісосічних ділянках. Середній відсоток некондиційних порубкових решток, що не підлягають утилізації та підлягають спалюванню складає не більше 5\% від утвореного загального об'єму порубкових залишків. При переробленні деревини виникають відходи деревини (2000.2.2.1 7 тирса деревини), які відносяться до IV класу небезпеки.

На території села знаходиться об'єкт екологічної мережі - заказник ботанічний «ОврамівськоІвашківський». Серійний номер 63-к/м-0-КО (оголошений рішенням 16 сесії XXI скликання Київської обласної ради народних депутатів від 10 березня 1994 року). Заказник розташований в межах КСП «Русанівське», с. Русанів Броварського району та займає площу 19 га [2].

В заказнику переважають липово-кленоводубові ліси. Це сформовані насадження, в деревостані яких переважає дуб, на деяких ділянках першого ярусу домішуеться ясен. Майже на всій площі добре розвинений підлісок з ліщини, поодиноко трапляеться бруслина европейська. У трав'яному покриві на більшій частині переважають яглиця звичайна, зірочник ланцетовидний, на підвищених ділянках - осока волосиста. Флористичне ядро утворюють типові неморальні види. Особливу наукову цінність являе тут місцезростання лілії лісової, занесеної до Червоної книги України. Із ссавців тут мешкають козуля та свиня дика, із птахів - дрібні співочі птахи, такі як зяблик, синиця велика, щеврик лісовий, соловейко звичайний, дрізд співочий, дрізд чорний, вівчарик жовтобровий [10].
Наступним вагомим чинником впливу на навколишне середовище $є$ накопичення відходів, утворення стихійних сміттезвалищ. В селі Русанів проводиться організований збір і вивезення побутового сміття місцевих мешканців, але не проводиться його сортування. В Київській області тільки у 44 населених пунктах, тобто 3,7\% від загальної кількості населених пунктів, впроваджено систему роздільного збирання відходів [11, с. 130]. Також у різних місцях виникають стихійні сміттезвалища, які свідчать про занадто низькі передбачені штрафи за цей злочин і низьку екологічну свідомість.

Висновки і пропозиції. Отже, еколого-біологічний стан села Русанів піддається впливу антропогенної діяльності. На сьогоднішній день значним джерелом забруднення повітря, шумового забруднення (житлові будинки впритул стоять до автомобільної дороги) на території с. Русанів є автомобільна дорога Н-07 Київ Суми - Юнаківка. Необхідно розробити заходи по зменшенню негативного впливу від діяльності автотранспорту на стан повітря.

Спостерігаеться на річці Трубіж порушення гідрологічного режиму, механічне забруднення, зниження рівня води, замулення, сповільнення швидкості течії. Також погіршуються показники якості води в наслідок потрапляння мінеральних, органічних речовин, пестицидів. Потрібно провести низку невідкладних заходів, які складаються 3 робіт по очищенню русла річки, від-

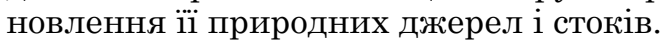

Зменшення площі лісових насаджень відбувається головним чином за рахунок зниження рівня Iрунтових вод і поширення серед ослаблених дерев різноманітних шкідників і хвороб. Рубки для головного користування, які здійснюе ДП «Бориспільський лісгосп» можуть посилювати негативні впливи, а тому підлягають дослідженню.

В селі Русанів потрібно розробити заходи по впровадженню системи роздільного збирання побутових відходів від населення для зменшення їх об’емів вивозу на сміттеві полігони. 


\section{Список літератури:}

1. Балюк С., Клаунінг Н., Четвертухіна Л., Коваль-Гончар М. Екологічні тренди в Україні: погляд громадян. Київ, 2021. 56 с. URL: http://library.fes.de/pdf-files/bueros/ukraine/17805.pdf (дата звернення: 17.11.2021).

2. Василюк О., Костюшин В., Норенко К., Плига А., Прекрасна Є., Коломицев Г., Фатікова М. Природно-заповідний фонд Київської області. Київ, 2012. 338 с.

3. Детальний план території земельної ділянки, площею 0.2000 га, кадастровий номер 3221288001:01:025:0027 для автомобільного заправочного комплексу по вул. Київська в селі Русанів, Броварського району Київської області. Том 1. Пояснювальна записка, додатки, графрічна частина. Бровари. 2020. URL: https://docs.google.com/viewer?a=v\&pid=sites\&srcid=cnVzYW5pdi1yYWRhLmdvdi51YXx3d3d8Z3g6NWY 2OGRkYmVlYzQyOGM0Mg (дата звернення: 17.11.2021).

4. Екологічний паспорт Київської області за 2019 р. 2020. URL: https://mepr.gov.ua/news/35913.html (дата звернення: 18.11.2021).

5. Звіт з оцінки впливу на довкілля планової діяльності зі спеціального використання лісових ресурсів в порядку проведення суцільних рубок головного користування та суцільних санітарних рубок. Державне підприемство «Бориспільське лісове господарство». 2019. URL: http://eia.menr.gov.ua/uploads/documents/4138/ reports/c9958a0aa60f888e5cceef1c2487a8a9.pdf (дата звернення: 17.11.2021).

6. Климюк А., Авраменко Н. Проблема відходів у Київській області Техногенно-екологічна безпека Украӥни: стан та перспективи розвитку : матеріали IX Всеукраїнської науково-практичної Інтернет-конференції (Ірпінь, 04-15 листопада 2019 р.). Ірпінь : Університет ДФС України, 2019. С. 24-27.

7. Ковалевський С.С. Вплив деревостанів Лісостепової Придніпровської височини на баланс вуглецю міста Біла Церква. Науковий вісник НЛТУ Украӥни. 2015. Вип. 25.10. С. 60-64.

8. Коцур Н.І. Екологічні ризики і здоров’я людини: сучасні проблеми та шляхи розв'язання. Молодий вчений. 2016. № 9.1 (36.1). С. 91-94.

9. Офіційний сайт села Русанів Броварського району. URL: http://www.rusaniv-rada.gov.ua/nase-selo (дата звернення: 15.11.2021).

10. Природно-заповідний фонд Київщини. Ботанічний заказник місцевого значення «Оврамівсько-Івашківський». URL: https://pryroda.in.ua/kyiv-region/zakaznyky/botanichnyy-zakaznyk-mistsevoho-znachennyaovramivsko-ivashkivskyy/ (дата звернення: 15.11.2021).

11. Регіональна доповідь про стан навколишнього природного середовища Київської області у 2020 році. Департамент екології та природних ресурсів Київської обласної державної адміністрації, 2021.

12. Рівень забруднення атмосферного повітря у селі Русанів. URL: https://www.saveecobot.com/maps/rusaniv (дата звернення: 24.11.2021).

13. Русанів // Вікіпедія: вільна енциклопедія. URL: https://uk.wikipedia.org/wiki/\%D0\%A0\%D1\%83\%D1\%81\%D0 \%B0\%D0\%BD\%D1\%96\%D0\%B2\#\%D0\%93\%D0\%B5\%D0\%BE\%D0\%B3\%D1\%80\%D0\%B0\%D1\%84\%D1\%96\%D1\%8F (дата звернення: 15.11.2021).

14. Сплодитель А.О., Кураєва І.В., Злобіна К.С. Особливості акумуляції важких металів у грунтах урбанізованих ландшафтів м. Бровари. Геологічний журнал. 2020. № 2. С. 39-51.

15. Стратегія розвитку Київської області на 2021-2027 роки. Київська обласна державна адміністрація, 2019. URL: http://koda.gov.ua/oblderzhadministratsija/publichna-informatsiya/strategiya-rozvitku-kiivskoi-oblast/ (дата звернення: 22.11.2021).

16. Шушпанов Д.Г. Детермінанти здоров’я населення: суть та особливості систематизації. Делографбія та соціальна еконоліка. 2015. № 2(24). С. 141-152.

\section{References:}

1. Balyuk S., Clowning N., Chetvertukhina L., Koval-Gonchar M. (2021) Ekolohichni trendy v Ukraini: pohliad hromadian [Environmental trends in Ukraine: citizens' point of view]. Kyiv: FEF Kyiv. Available at: http://library.fes.de/pdf-files/bueros/ukraine/17805.pdf (accessed 17 November 2021). (in Ukrainian)

2. Vasilyuk O., Kostyushin V., Norenko K., Pliga A., Prekrasna E., Kolomytsev G., Fatikova M. (2012) Pryrodnozapovidnyi fond Kyivskoi oblasti [Nature Reserve Fund of Kyiv Region]. Kyiv: National Ecological Center of Ukraine. (in Ukrainian)

3. GeoFactory (2020) Detalnyi plan terytorii zemelnoi dilianky, ploshcheiu 0.2000 ha, kadastrovyi nomer 3221288001:01:025:0027 dlia avtomobilnoho zapravochnoho kompleksu po vul. Kyivska v seli Rusaniv, Brovarskoho raionu Kyivskoi oblasti. Tom 1. Poiasniuvalna zapyska, dodatky, hrafichna chastyna [Detailed plan of the territory of the land plot, with the area of 0.2000 hectares, cadastral number 3221288001:01:025:0027, for the automobile gas station located at Kyivska street, Rusaniv village, Brovary district, Kyiv region. Volume 1. Explanatory note, addenda, graphics]. Brovary: GeoFactory. Available at: https://docs.google.com/viewer?a=v\&pid=sites\&srcid=cnVzYW5pdi1yYWRhLmdvdi51YXx3d3d8Z3g6NWY2OGRkYmVlYzQyOGM0Mg (accessed 17 November 2021).

4. Kyivska oblasna derzhavna administratsiia (2020) Ekolohichnyi pasport Kyivskoi oblasti za 2019 r. [Ecological passport of Kyiv region for 2019]. Available at: https://mepr.gov.ua/news/35913.html (accessed 18 November 2021).

5. Zvit $\mathrm{z}$ otsinky vplyvu na dovkillia planovoi diialnosti zi spetsialnoho vykorystannia lisovykh resursiv $\mathrm{v}$ poriadku provedennia sutsilnykh rubok holovnoho korystuvannia ta sutsilnykh sanitarnykh rubok. Derzhavne pidpryiemstvo "Boryspilske lisove hospodarstvo» (2019) [Report on the environmental impact of the planned activities for the special use of forest resources during the continuous deforestation for the main use and in course of continuous sanitary deforestation. State Enterprise "Boryspil Forestry"]. Available at: http://eia.menr.gov.ua/ uploads/documents/4138/reports/c9958a0aa60f888e5cceef1c2487a8a9.pdf (accessed 17 November 2021).

6. Klimyuk A., Avramenko N. (2019) Problema vidkhodiv u Kyivskii oblasti [The problem of waste in Kyiv region]. Proceedings of the Tekhnohenno-ekolohichna bezpeka Ukrainy: stan ta perspektyvy rozvytku: materialy IX Vseukrainskoi naukovo-praktychnoi Internet-konferentsii (Ukrainian, Irpen, November 04-15, 2019), Irpen: University of the State Fiscal Service of Ukraine, pp. 24-27.

7. Kovalevsky S.S. (2015) Vplyv derevostaniv Lisostepovoi Prydniprovskoi vysochyny na balans vuhletsiu mista Bila Tserkva. [The influence of forest stands of the Forest-Steppe Dnieper Upland on the carbon balance of the city of Bila Tserkva]. Scientific Bulletin of UNFU, vol. 25.10, pp. 60-64.

8. Kotsur N.I. (2016) Ekolohichni ryzyky i zdorovia liudyny: suchasni problemy ta shliakhy rozviazannia [Environmental risks and human health: current problems and solutions]. Young Scientist, vol. 36.1, no. 9.1, pp. 91-94. 
9. Ofitsiinyi sait sela Rusaniv Brovarskoho raionu [Official site of Rusaniv village of Brovary district]. Available at: http://www.rusaniv-rada.gov.ua/nase-selo (accessed 15 November 2021).

10. Pryrodno-zapovidnyi fond Kyivshchyny. Botanichnyi zakaznyk mistsevoho znachennia «OvramivskoIvashkivskyi» [Nature Reserve Fund of Kyiv Region. "Ovramivsko-Ivashkivskyi» Botanical Reserve of Local Importance]. Available at: https://pryroda.in.ua/kyiv-region/zakaznyky/botanichnyy-zakaznyk-mistsevohoznachennya-ovramivsko-ivashkivskyy/ (accessed 15 November 2021).

11. Departament ekolohii ta pryrodnykh resursiv Kyivskoi oblasnoi derzhavnoi administratsii (2021) Rehionalna dopovid pro stan navkolyshnoho pryrodnoho seredovyshcha Kyivskoi oblasti u 2020 rotsi [Regional report on the state of the environment of Kyiv region in 2020].

12. Riven zabrudnennia atmosfernoho povitria u seli Rusaniv [The level of air pollution in the Rusaniv village]. Available at: https://www.saveecobot.com/maps/rusaniv (accessed 24 November 2021).

13. Rusaniv. Vikipediia: vilna entsyklopediia [Rusaniv. Wikipedia: free encyclopedia]. Available at: https://uk.wikipedia.org/ wiki/\%D0\%A0\%D1\%83\%D1\%81\%D0\%B0\%D0\%BD\%D1\%96\%D0\%B2\#\%D0\%93\%D0\%B5\%D0\%BE\%D0\%B3\%D1 $\% 80 \% \mathrm{D} 0 \% \mathrm{~B} 0 \% \mathrm{D} 1 \% 84 \% \mathrm{D} 1 \% 96 \% \mathrm{D} 1 \% 8 \mathrm{~F}$ (accessed 15 November 2021).

14. Splodytel A.O., Kuraeva I.V., Zlobina K.S. (2020) Osoblyvosti akumuliatsii vazhkykh metaliv u gruntakh urbanizovanykh landshaftiv $\mathrm{m}$. Brovary [Features of accumulation of heavy metals in soils of urban landscapes of Brovary city]. Geological journal, no. 2, pp. 39-51.

15. Departament ekolohii ta pryrodnykh resursiv Kyivskoi oblasnoi derzhavnoi administratsii (2019) Stratehiia rozvytku Kyivskoi oblasti na 2021-2027 roky [Strategy of Development of Kyiv region for 2021-2027]. Available at: http://koda.gov.ua/oblderzhadministratsija/publichna-informatsiya/strategiya-rozvitku-kiivskoi-oblast/ (accessed 22 November 2021).

16. Shushpanov D.G. (2015) Determinanty zdorovia naselennia: sut ta osoblyvosti systematyzatsii [Determinants of public health: the essence and features of systematization]. Demography and social economy, vol. 24, no. 2 , pp. 141-152. 